\title{
Notas sobre o amor e a melancolia: da estrutura à resistência
}

\author{
Notes on Love and Melancholy: From the Structure to the Resistance
}

\begin{abstract}
Cassiana Lopes Stephan' (iD) 0000-0003-2687-1202
'Universidade Federal do Paraná, Programa de Pós-Graduação em Filosofia, Curitiba, PR, Brasil.80060-000 - pgfilos@ufpr.br
\end{abstract}

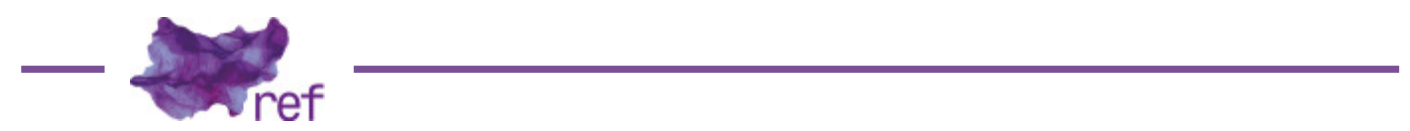

Resumo: Michel Foucault, no texto "Un Plaisir si Simple", mostra-nos que a miséria do amor moderno se fundaria sobre a ressignificação psicanalítica do remorso cristão. Por outro lado, Judith Butler nos explica, ao problematizar a relação entre a psicanálise e a matriz heterossexual, que o amor é melancólico e que o mecanismo da melancolia constitui a identidade de gênero. Conforme Butler, a melancolia parece ter duas disposições, uma estruturada e outra desviante. A melancolia estruturada garantiria a "cura" dos desvios sexuais mediante a aplicação dos códigos fálicos ao desejo do sujeito. Inversamente, a melancolia desviante estaria ligada à subversão da heteronormatividade. A partir disso, interessa-nos interrogar em que medida a interpretação foucaultiana do prazer concernente às transgressões amorosas se articularia à disposição desviante da melancolia butleriana; e, finalmente, gostaríamos de indicar algumas convergências entre a melancolia criativa e a ética antiga do cuidado de si.

Palavras-chove: prazer; culpa; heteronormatividade; melancolia; amor.

Abstract: Michel Foucault, in the text "Un Plaisir si Simple", shows us that the misery of the modern love is based on the psychoanalytic resignification of the Christian remorse. On the other hand, Judith Butler explains, when she problematizes the relation between the psychoanalysis and the heterosexual matrix, that love is melancholic and that the mechanism of the melancholy constitutes the gender identity. According to Butler, the melancholy seems to have two dispositions, one structured and another deviant. The structured melancholy ensures the "healing" of the sexual deviations by applying the phallic codes to the desire of the subject. Conversely, the deviant melancholy would be linked to the subversion of the heteronormativity. On this basis, we are interested in questioning in what extend the Foucauldian interpretation of the pleasure concerning to the love transgressions is articulated to the deviant disposition of the Butlerian melancholy; and, finally, we would like to indicate some links between the creative melancholy and the ancient ethics of the care of the self.

Keywords: Pleasure; Guilt; Heteronormativity; Melancholy; Love.

\section{Introdução}

No texto "Un Plaisir si Simple" (Michel FOUCAULT, 2001, p. 777-779), Foucault problematiza os mecanismos de interesse que regem uma sociedade cuja civilidade se funda na defesa pela vida engajada na reprodução compulsória da identidade que faz convergir a vontade dos sujeitos econômicos. Neste escrito, Foucault nos encoraja a abandonar a racionalização que rege o aparecimento do homo oeconomicus, a qual corresponde ao cálculo empirista que compreende a maior felicidade do maior número como uma conta apática que visa à total ausência de dor, já que "o caráter doloroso ou não-doloroso da coisa constitui, em si, um motivo de opção além do qual não se pode ir" (FOUCAULT, 2008, p. 371). Para Foucault, na modernidade, a promoção da vida individual e da vida social passa a se atrelar à propagação do bem-estar e este parece afastar os sujeitos da simples experimentação do prazer, na medida em que os 
subordina ao limitador regressivo da dor. Dessa maneira, os prazeres que irrompem como efeito dos esforços de resistência, transgredindo e subvertendo a peremptória promulgação da única identidade capaz de corroborar a multiplicação do bem-estar, devem ser banidos pelas instituições responsáveis por assegurar a supremacia deste tipo de vida como o mais alto bem ou como o mais alto interesse da sociedade (FOUCAULT, 2008, p. 409).

Assim, sem medo de desestruturar a apatia da moderna civilização, Foucault nos mostra que o prazer não depende do bem-estar econômico-social ou da máxima supressão da dor. Para Foucault, o prazer é experienciado a partir da criação de um espaço e de um momento no qual morreríamos "livres de toda identidade" - de toda identidade fundamentada na fórmula que, ao associar o mal-estar privado e público à resistência, inculca aos sujeitos o medo e a culpa em relação à transgressão e à subversão (FOUCAULT, 2001, p. 779 [tradução nossa]). A franqueza de Foucault no texto "Un Plaisir si Simple" pode ser caracterizada pelo conselho que ele direciona aos filantropos, os quais praticam a benevolência social em nome de seus próprios interesses egoístas: "Se vocês realmente querem que o número de suicídios diminua, assegurem-se de que as pessoas que se matam somente o façam por uma vontade refletida, tranquila e livre de incerteza" (FOUCAULT, 2001, p. 778 [tradução nossa]). A partir destas palavras, Foucault parece descriminalizar e despatologizar o suicídio, na medida em que (a) o desvincula do remorso relativo à infração das regras que prescrevem a felicidade como sucesso econômico-social e (b) o atrela ao prazer decorrente da criticidade do sujeito em relação às identidades delimitadas pela normalidade afetiva dos amores interessados na salubridade da civilização. De modo geral, a miséria do amor moderno parece se fundamentar, por um lado, na ideia "de um sujeito de interesse, ou seja, um sujeito como princípio de interesse, como ponto de partida de um interesse ou lugar de uma mecânica de interesses" (FOUCAULT, 2008, p. 372) e, por outro lado, na ressignificação psicanalítica do remorso cristão, já que a culpa seria imputada à criatividade crítica do melancólico que, quando ultrapassa os limites da heteronormatividade, assassina a própria libido ou toda a figuração fálica que a sustenta.

Em contrapartida, as análises de Judith Butler (1997) em relação ao potencial subversivo da melancolia gay e da melancolia feminina remetem-nos às considerações de Foucault acerca dos prazeres suicidas. Para Butler (1997), a melancolia corresponde a um mecanismo psíquico que constitui a identidade de gênero (p. 133). Butler nos explica que a incorporação melancólica do gênero consiste em um acontecimento que se estabelece por meio da intersecção entre o sujeito e o significante que o demanda, o qual está vinculado à simbolização fálica manifestada na imagem do Outro. A partir de Butler, talvez nós possamos afirmar que a melancolia possui duas disposições, a saber, uma estruturada e outra desviante. A melancolia estruturada ou oblativa seria regida pela lei patriarcal da psicanálise que curaria os desvios da sexualidade por meio da aplicação dos códigos fálicos ao sujeito de desejo. Estas normas falocêntricas parecem conduzir à elaboração de uma reflexividade culposa. Diferentemente, a melancolia desviante ou criativa estaria vinculada à subversão da heteronormatividade, pois concerniria ao modo de subjetivação que se daria por meio da crítica em relação aos poderes e saberes do Falo. Com base nisso, supomos que as mazelas do amor moderno estão relacionadas à normalização da melancolia oblativa, um processo que institui a máscara fálica na psiquê dos sujeitos, estruturando seus laços sociais pela harmonização entre o interesse civil e a heteronormatividade do desejo. A melancolia estruturada funcionaria em razão da interdição da simplicidade dos prazeres que manifestam o alcance ético-político dos afetos atrelados ao suicídio da identidade heteronormativa e, simultaneamente, ela operaria em virtude da promulgação da moral e dos bons costumes - dos códigos que imputam a docilidade materno-matrimonial ao modo de ser mulher e o vigor paterno-patriarcal ao modo de ser homem.

Por conseguinte, neste artigo, nós tentaremos (a) mostrar em que medida a interpretação foucaultiana dos prazeres transgressivos estaria atrelada à disposição desviante da melancolia butleriana; e (b) indicar algumas conexões entre a melancolia criativa e o cuidado de si helenísticoromano. Dessa forma, nós recorreremos às análises de Foucault sobre a estética da existência nas antigas asceses filosóficas, mas também às interpretações desenvolvidas por Butler no segundo capítulo de Gender Trouble: feminism and subversion of identity, intitulado "Prohibition, Psychoanlisys, and the Production of the Heterosexual Matrix" (BUTLER, 2002, p. 45-100), bem como àquelas elaboradas no livro The Psychic Life of Power: Theories in Subjection. A hipótese de nossa atual pesquisa é a de que o remorso ligado ao suicídio da identidade heteronormativa é recuperado da cultura sacrificial do cristianismo, para a qual a renúncia de si mesmo seria a expressão mais poderosa e verdadeira do amor, e reaclimatado pela lógica do sujeito de interesse na medida em que, para a civilidade moderna, o suicídio da identidade heteronormativa corresponderia simultaneamente a um ato doentio em relação a si mesmo e a um crime contra o bem-estar social.

Com efeito, nós ainda não somos capazes de mostrar os detalhes da articulação entre o sujeito de interesse, o sujeito de direito e o sujeito de desejo no que concerne à constituição político-cultural da sociedade civil. Sendo assim, por meio da estética da existência de Foucault e das análises de Butler sobre a melancolia, nós iremos nos deter na apresentação da ideia 
segundo a qual as misérias do amor moderno estariam ligadas à ressignificação psicanalítica do remorso cristão. Os códigos fálicos parecem recontextualizar o dispositivo da culpabilidade, compreendendo-o como um tipo de tomada de consciência em relação aos desvios de um amor que infringe a finalidade reprodutiva da vida conjugal, na medida em que se abre à experiência dos prazeres que decorrem de desejos proibidos, de desejos que, de acordo com tais códigos fálicos, precisariam ser negados em virtude da salubridade psicossocial dos sujeitos amantes. Além disso, é importante ressaltar que, neste ensaio, nós elaboraremos as considerações de Butler e de Foucault sobre a relação entre o amor, a identidade de gênero e a resistência ético-política de um ponto de vista exclusivamente filosófico e jamais a partir de uma abordagem clínica. No nosso texto, nós tentaremos apontar tanto algumas suposições acerca das críticas de Butler no que se refere à psicanálise lacaniana e freudiana, quanto algumas acerca das análises de Foucault sobre a importância ética dos elos amorosos. Portanto, não se trata de negar a importância da psicanálise para a dessubjetivação dos sujeitos. Pelo contrário, gostaríamos de indicar como as análises filosóficas de Butler contribuíram para a subversão da linguagem patriarcal da psicanálise e como as reflexões de Foucault sobre a estética da existência seriam capazes de recolocar em questão o alcance da análise psicanalítica, conectando-a ao eixo do cuidado de si. O radicalismo da crítica de Butler e de Foucault em relação ao discurso psicanalítico sobre o gênero não busca suprimir esta prática e esta esfera teórica, mas, antes, revisar seus limites e subverter seus agenciamentos. Isso significa que as discussões filosóficas em torno da psicanálise fazem atenção à pertinência sócio-política desta, já que a psicanálise contribui, na atualidade, em razão da modificação crítica de seu fundamento patriarcal, para a legitimação social de diversas identidades cujas práticas manifestam cotidianamente a resistência ético-política.

\section{A sedimentação do amor moderno}

Foucault nos explica que na Antiguidade helenístico-romana o amor correspondia a uma ação ético-política amparada pelo desejo e pelo prazer. O amante era aquele que desejava o ato de amar e que experienciava o prazer como a alegria decorrente do esforço (érgon) despendido nesta prática transfiguradora. A experiência autárquica do amor condizia à exercitação do cuidado de si helenístico-romano, pois este constituía uma prática social que dava "lugar a relações interindividuais, a trocas e comunicações e até mesmo a instituições" (FOUCAULT, 201 1a, p. 50). Segundo Foucault, para cínicos e estoicos o amor era uma atividade crítica que insurgia contra os valores viciosamente difundidos pelas instituições vigentes na sociedade. A vivência ética do amor era incitada e incitava a crítica em relação à educação recebida, à estrutura do casamento, ao meio familiar e à configuração institucional da política (FOUCAULT, 2010, p. 85-88). A realização da crítica social dependia da criação de amores parresiásticos, os quais eram capazes de performar, mediante os olhos vaidosos da sociedade, uma amizade livre de pudores e de interesses funcionais ou materiais. De fato, a maioria da sociedade concebia a riqueza, a fama e o poder como bens que poderiam ser adquiridos, trocados ou expandidos por meio da socialização. Contudo, para cínicos e estoicos estas coisas eram indiferentes (adiáphorol) à exercitação ética do amor por si, pelos outros e pelo mundo (DIOGENES LAERTIUS, 1972, VII. 102-107). A filósofa cínica Hiparquia, por exemplo, renunciou e subverteu o valor estatutário do casamento quando se uniu ao cínico Crates por paixão à maneira pela qual ele conduzia a própria vida e não por interesse funcional (DIOGENES LAERTIUS, 1972, VI.96). Estes amores rebeldes constituíam práticas sociais que subvertiam tanto as relações de posse, atreladas à servidão doméstica da esposa, dos filhos e dos escravos, quanto os laços táticos estabelecidos e mantidos pela bajulação política. Plutarco nos explica que os laços que se estabelecem por bajulação são hipócritas e não contribuem para a transformação ética dos envolvidos. Os louvores do bajulador em relação ao bajulado são fingidos, pois tais elogios são deslindados em virtude da aquisição, por parte do lisonjeador, de status social ou material (PLUTARCO, 2011, p. 26-27). Portanto, os bons relacionamentos eram aqueles capazes de ensejar a constituição autárquica dos sujeitos, isto é, aquele que ama não estabelece dependência, sujeição ou opressão, mas elabora a própria liberdade (eleuthería) na medida em que corrobora a liberdade do outro (EPICTETO, 2012).

Desse modo, para Foucault, o prazer era experienciado como a sensação que se seguia do ato constituído pela recusa crítica em relação às convenções que vigoravam na cultura e pela constituição autárquica de si mesmo (FOUCAULT, 2011 b, p. 70-71). Talvez possamos admitir que esta alegria prazerosa correspondia a um sentimento moderado que manifestava a posse de si, mas também a transgressão das medidas ou dos limites culturais homologados pelos vícios e preconceitos da sociedade (Tad BRENNAN, 2006, p. 299, 307). ${ }^{1}$ Para Foucault, tal prazer se exprimiria como o rompante suicida do sujeito que nega a elaboração de uma individualidade espelhada nos

\footnotetext{
'Como nos explica Brennan, a alegria prazerosa era concebida como uma sensação serena que os estoicos exprimiam pelo uso do substantivo gregro "khára" e pelo termo latino "gaudium". Estas palavras se distinguiam respectivamente dos conceitos "hédonê" e "voluptas", os quais significavam um prazer fugaz e violento decorrente tanto dos abusos da alma quanto dos abusos do corpo.
} 
ditames sociais e que, ao mesmo tempo, busca se transformar a partir da experiência subversiva do amor. Por outro lado, as condutas afetivas instauradas a partir da modernidade psicanalítica, a qual continua a fundar e justificar as diversas modalidades de nossa cultura amorosa, parecem ser regidas pela univocidade da relação entre o sujeito de desejo e o objeto desejado. Isso significa que o amor passa a ser interpretado como uma estrutura psíquica que sustenta o desejo subjetivo pelo objeto fálico e que a ação ético-política não é mais determinante para a experiência amorosa e para a constituição da consciência dos amantes. Foucault nos explica que os saberes e os poderes concernentes ao amor moderno passam a ser subsumidos à função privilegiada do desejo:

[...] na fórmula grega, os "atos" jogam um papel preponderante, o prazer e o desejo eram subsidiários: ato-prazer-(desejo). [...] Eu diria que a "fórmula" moderna é o desejo - que é sublinhado teoricamente e aceito na prática, dado que você deve liberar o seu desejo; os atos não são tão importantes, quanto ao prazer, ninguém sabe o que ele é! (FOUCAULT, 2001, p. 1219 [tradução nossa]).

Com base nas considerações de Butler acerca da modernidade amorosa, talvez possamos afirmar que os discursos psicanalíticos desvinculam o desejo da ação ético-política e da alegria prazerosa, na medida em que o relacionam ao sexo e ao gênero. Segundo Butler (2002), a inteligibilidade dos amores modernos se deve à continuidade e à coerência entre a ficção atrelada à manifestação ontológica do sexo, à disposição natural do desejo e à normalidade psicossocial do gênero (p. 23, 30). Nesse sentido, o desejo jogaria um papel fundamental no que tange às condutas afetivas da modernidade porque concerniria ao acontecimento psíquico que irrompe da articulação entre a verdade sobre a natureza e a verdade sobre a cultura do sujeito amoroso. Para Butler, as leis da biologia dão origem à ficção de uma realidade binária que corresponde ao estatuto ontológico do macho e da fêmea, ao passo que as leis da psicanálise produzem, a partir destas duas possibilidades ôntico-genitais, a realidade cultural daquele que tem o Falo e a realidade cultural daquela que é o Falo. Em outras palavras, como nos explica Butler a propósito da psicanálise lacaniana, o binarismo forjado, disseminado e investido pelo discurso do positivismo científico é metonimicamente imitado pela imagem do Falo, a qual é elaborada por meio de "uma linguagem estruturada pela lei patriarcal e pelos seus mecanismos de diferenciação" (BUTLER, 2002, p. 56 [tradução nossa]). Dessa maneira, as distinções psicanalíticas acerca dos desejos masculinos e femininos advêm da mescla entre a fábula médico-científica do naturalismo binário e o mito filosófico-antropológico do patriarcado, de tal modo que, de acordo com a narrativa lacaniana acerca do amor, o Falo vem a ser a "função pivô [...] que nos permite situar aquilo que dele se distingue, ou seja, $a$, e no pequeno a enquanto pequeno $a$, a função geral do objeto de desejo" (Jacques LACAN, 2010, p. 462). Faz-se importante ressaltar que para Butler, como para Foucault, o discurso psicanalítico não passa de mais uma explicação possível ao amor, pois a verdade acerca da subjetividade e da realidade que a permeia consiste em uma ficção alicerçada pelo poder atinente à aplicação prática de saberes que reúnem no Outro, neste caso o Falo, a universalidade normativa da significação social. Butler (2001) se questiona:

[...] em que sentido isto é ficção? Foucault se refere a "uma prática histórico-filosófica [na qual] se trata de fazer a própria história, de fabricar a história, como por ficção [de faire comme par fiction], nos termos em que ela estaria atravessada pela questão da relação entre as estruturas de racionalidade que articulam o discurso verdadeiro e os mecanismos de subjetivação que estão ligados a ele". Há, dessa maneira, uma dimensão da metodologia (crítico-genealógica) que parte da ficção, que desenha linhas ficcionais entre a racionalização e a dessubjetivação, entre o nexo saber-poder e a sua fragilidade ou limite (p. 15 [tradução nossa]).

De acordo com Butler, a repetição compulsória dos saberes fabulados faz com que o aspecto ficcional dos discursos seja obliterado ou disfarçado pela magnanimidade da lei, a qual apresenta a ficção histórico-filosófica como um código universal fundado em uma verdade absoluta. Parece ser, portanto, sob o bojo da repetição compulsória que surgem as narrativas médico-científicas de dimensão político-moral, as quais se pretendem definitivas e únicas no que tange à determinação da natureza humana. Em outras palavras, a reiteração acrítica dos discursos nos impede de vislumbrar a pluralidade das linguagens que coexistem nas distintas circunstâncias espaço-temporais e, por conseguinte, de praticar a identidade como um repente criativo ou performático que não precisa se ater aos limites da Razão universal. Para Butler (2002), "o sujeito não é determinado pelas regras por meio das quais é gerado porque a significação não é um ato fundante, mas sim um processo regulatório de repetição que esconde a si mesmo e reforça as suas próprias regras precisamente através da produção de efeitos de substancialização" (p. 185 [tradução nossa]). Assim, a ciência explica o amor como uma sinapse que conecta as funções cerebrais às genitais, ou melhor, para a biologia e para a medicina, o amor corresponde a uma necessidade fisiológica que garante a perpetuação da espécie humana. O princípio teleológico da reprodução justifica o discurso científico que descreve e prescreve a simetrização da diferença entre o corpo do macho e o corpo da fêmea. Ademais, 
Butler nos mostra que a reprodução também é pressuposta, reiterada e racionalizada pela lei do patriarcado, já que os filhos homens manifestariam a consolidação da ligação e da diferença entre os clãs patriarcais envolvidos em determinado intercurso social, enquanto que as filhas mulheres viabilizariam tal comunicação. Mais especificamente, as mulheres serviriam ao casamento para facilitar a comutação identitária entre os homens que constituem diferentes linhagens paternais: "a noiva funciona como um termo relacional entre grupos de homens; ela não tem uma identidade e nem mesmo troca uma identidade por outra. Ela reflete a identidade masculina precisamente por corresponder ao lugar de sua ausência" (BUTLER, 2002, p. 50 [tradução nossa]).

No contexto do patriarcado, a maternidade e o matrimônio exprimem a condicionalidade das mulheres ao protagonismo político-social dos homens, pois a mãe e a noiva não constituem identidades atreladas à elaboração de uma subjetividade feminina, mas correspondem a instrumentos manuseados pelos homens que buscam fortalecer a imagem pública de suas linhagens por meio da realização de estratégicas amizades masculinas. Segundo a lei do patriarcado, as mulheres concernem aos objetos que instituem a relação de reciprocidade entre os homens, a qual "é a condição de uma relação radical de não-reciprocidade entre homens e mulheres e de uma relação, por assim dizer, de não-relação entre mulheres" (BUTLER, 2002, p. 53 [tradução nossa]). O patriarcado parece operar de maneira a distinguir o estatuto público da amizade e a dimensão privada do amor. Por um lado, a amizade condiz à relação horizontal entre os chefes de família; por outro lado, o amor reúne, numa única e mesma fórmula, (a) a diferenciação simétrica entre o corpo do homem e o corpo da mulher e (b) a instrumentalização hierárquica deste objeto feminino por aquele sujeito masculino, visto que a organização econômica do matrimônio se articula, sob a clave da misoginia, à dialética do senhor e do escravo. O amor pelas mulheres é vivenciado como a apropriação de um objeto matrimonial que assegura a reprodução e intermedeia a instituição de amizades masculinas, demasiado masculinas.

Butler explica que a configuração psicanalítica do bom funcionamento do desejo subjetivo se atrela ao cenário biológico-patriarcal sobre o qual o amor moderno é performado. A aparência universal do discurso da psicanálise provém da mistura entre o saber médico-científico e o saber filosófico-antropológico, contudo, faz-se interessante apontar que a eficácia prática da linguagem psicanalítica também depende da moralização do desejo. O caráter terapêutico da psicanálise residiria na delimitação da salubridade e da decência do desejo a ser liberado pelo sujeito amoroso. Conforme Butler, nós podemos afirmar que a parametrização psicanalítica do mundo interior se institui por meio da criação de uma estrutura de significação que deve ser mobilizada como o fundamento do desejo amoroso (BUTLER, 2002, p. 56). Com base nisso, nós gostaríamos de indicar a hipótese segundo a qual este símbolo pré-ontológico da psicanálise precisaria arcar com a morte de Deus, precisaria desbancar, por meio da invenção de um símbolo tão inacessível quanto o divino, o discurso nietzschiano anunciado pelo homem louco: "'Procuro Deus! Procuro Deus!' [...] 'Para onde foi Deus?', gritou ele, 'já lhes direi! Nós o matamos - vocês e eu. Somos todos assassinos!" (Friedrich NIETZSCHE, 2012, Aforismo 125, p. 137).

Ora, parece que, com a morte de Deus, as identidades instanciadas pelos códigos universais baseados na transcendência divina foram subvertidas. A morte de Deus abriria espaço para a experiência da morte de um si mesmo determinado pelos deveres e interdições legitimados pela codificação pastoral e inquisitória ligada à simbologia cristã da divindade. O suicídio das identidades constituídas à imagem e semelhança de Deus conduziria à criação de uma anatomia profana que se multiplicaria pela incitação às práticas e às reflexividades críticas (FOUCAULT, 2001, p. 1393). Estas implicariam a sensação paradoxal da simplicidade de um prazer que não advém da supressão total da dor, mas do esforço vinculado à transformação ética de si. No contexto em que o Outro deixa de ser simbolizado pela figuração transcendental de Deus, a psicanálise parece emergir como a ciência que buscaria salvar os amantes desestruturados pela morte do divino. Não se trata de uma salvação prometida à eternidade da alma que remonta ao reino dos fins, mas sim de uma cura analítica dos indivíduos que compõem a sociedade civil e que podem contribuir para o bem-estar iminente ao contexto político-cultural delimitado pelo espaço e pelo tempo do interesse econômico-fálico. Parece que, em seu limiar patriarcal, a psicanálise se interessara pela cura da estrutura psíquica da consciência melancólica do homem dócil e da mulher viril, já que estes sujeitos teriam surgido no intervalo da morte de Deus e não teriam sentido a Sua falta, rendendo-se, num impulso suicida, à experiência dos amores lascivos e à constituição de identidades desviantes. Esta falta precisaria ser elaborada como culpa, como luto pela morte do Outro. Para tanto, fez-se necessário transferir o amor que este sujeito sentia por Deus a um outro objeto, que não o si mesmo aberto a transgressões possíveis. O amor-próprio do melancólico desviante deve ser curado pela introdução de um Outro capaz de ratificar e retificar as verdades divinas concernentes ao binarismo anatômico dos corpos de mulheres e homens. Supomos, então, que o Falo teria aparecido como o objeto que estabeleceria a continuidade 
entre o sexo, o desejo e o gênero sob a luz da tradicional lei do patriarcado, de maneira a sedimentar o amor moderno na heteronormatividade. ${ }^{2}$

Conforme Butler, o Falo carrega o peso da tradição binária, patriarcal e moralizante difundida pela filosofia, pela antropologia, pela ciência e pela religião. Portanto, o Falo ainda corresponde a um símbolo inventado e aplicado por uma perspectiva heterossexual masculina, que busca a sua própria universalização por meio da proibição da diferença atrelada à construção subversiva dos amores femininos e dos amores gays (BUTLER, 2002, p. 63). Talvez possamos afirmar que a novidade do símbolo fálico em relação ao Deus recém-assassinado se vincule ao fato de que a psicanálise, diferentemente das doutrinas cristãs, não busca purificar o desejo por meio de atos confessionais que expurgariam os pecados da carne (FOUCAULT, 2014, p. 94), mas sim estruturar o desejo subjetivo a partir da normalização da melancolia oblativa, a qual concerne a um estágio psíquico que garantiria a adequada liberação dos desejos amorosos, na medida em que, segundo Butler, a heterossexualidade resultaria da perda não elaborada da possibilidade do desejo homossexual. Como afirma Foucault, enquanto a fórmula do amor cristão "coloca o acento sobre o desejo na tentativa de suprimi-lo" (FOUCAULT, 2001, p. 1219 [tradução nossa]), a fórmula do amor moderno o realça na tentativa de reiterar a heteronormatividade sob o viés da liberação. Parece que a psicanálise salvaria o amor da luxúria ensejada pela morte de Deus ao patologizar a psiquê dos indivíduos que vivenciam a multiplicidade dos prazeres na recusa do Outro, ou melhor, na perda da normatividade do desejo que afirma a heterossexualidade e, ao mesmo tempo, condena outras formas de amar. A psicanálise naturalizaria a psiquê do heterossexual que libera um desejo pudico, o qual, ao invés de incitar o prazer, causa a nostalgia relativa à jouissance experienciada naquele passado, ainda porvir, vislumbrado pelo homem louco que suicidara o si mesmo constituído à imagem e semelhança do Simbólico (BUTLER, 2002, p. 71).

Butler nos mostra que a liberação do desejo heterossexual dispensa a simplicidade dos prazeres quando interdita a possibilidade dos desejos homossexuais a fim de garantir a salubridade dos sujeitos amantes. Estes direcionam seus olhares ao Falo e incorporam-no sob a forma mascarada do ser ou sob a forma narcísica do ter (LACAN, 2010, p. 471). Segundo Butler, a partir da distinção entre o ser e o ter que se estabelece no Falo, a psicanálise lacaniana contribuiria para a sedimentação do amor moderno na heteronormatividade que, por ter o Falo como o pivô do desejo, atribui à mulher a função de mascarar o fato de que ela não o tem e, simultaneamente, a de proteger a referida falta para que a sua necessidade de ser amada seja correspondida por aquele que tem o Falo. Para Lacan, no caso das mulheres, isso "pode ser vivido muito penosamente sob a forma do Penisneid [...]" (LACAN, 2010, p. 289). Com base nisso, Butler explica que, de acordo com a narrativa psicanalítica, a salubridade mental dos amantes dependeria da incorporação do Falo, a saber: (a) da afirmação do amor reprodutivo e hierárquico entre pessoas simetricamente distintas, no que tange à disposição anatômica de seus órgãos sexuais, e (b) da renúncia dos prazeres atrelados à transgressão gay ou feminina/feminista deste desejo pudico, dado que "a identidade heterossexual se conquista pela incorporação melancólica do amor que renuncia: o homem que insiste na coerência de sua heterossexualidade afirmará que nunca amou outro homem [...]" (BUTLER, 1997, p. 139 [tradução nossa]). ${ }^{3}$

De acordo com esta nova simbologia, a disposição natural do desejo feminino estaria orientada àquilo que as mulheres não têm, ao passo que a disposição natural do desejo masculino estaria orientada à reapresentação daquilo que os homens têm. Isso significa que a feminilidade é elaborada pela incorporação de uma máscara fálica, ou seja, na matriz heterossexual o gênero feminino é instituído como um objeto que representa a subjetividade daquele que tem o Falo. A feminilidade heterossexual é significada pela demanda da subjetividade masculina, já que a mulher é constituída como um sujeito de desejo somente quando objetificada em razão do Falo que Ihe falta. O olhar que a mulher possui sobre si mesma seria engendrado pelo olhar masculino do Outro, de tal modo que a mulher se conceberia como um objeto de desejo cujo destino corresponderia à maternidade e ao matrimônio. Diferentemente, o olhar que o homem possui sobre si mesmo seria produzido por meio da perspectiva mascarada que o representa, ou melhor, pelo ponto de vista da mulher que reflete a masculinidade. Nesse sentido, talvez possamos admitir que a constituição da consciência masculina é narcísica, pois o homem heterossexual só consegue - ou só deve - amar a mulher que carrega em si o espelho fálico:

\footnotetext{
2 Vale ressaltar que o Falo já fora cultuado na Antiguidade por diferentes povos como símbolo da fecundidade ou da força regeneradora do sol da primavera, tal como mostra Jacques-Antoine Dulaure (2007) em seu livro Le culte du Phallus chez les anciens et le modernes (Genève: Arbre d'or). Portanto, a substituição falocêntrica do Deus cristão não parece ser uma suposição desarrazoada, visto que ela estaria provavelmente galgada em antigas narrativas míticoreligiosas.

${ }^{3}$ A identidade heterossexual parece ser instituída por meio da fusão do si mesmo com o Falo, de tal modo que as mulheres se fundem aos homens e os homens se fundem a si mesmos, visto que a linguagem fálica parece imitar a reciprocidade patriarcal entre os homens, a qual se constituía, como explicamos anteriormente, pela não reciprocidade entre homens e mulheres.
} 
Diz-se que as mulheres são o Falo no sentido de que elas mantêm o poder de refletir ou de representar a "realidade" auto-fundamentadora do sujeito masculino; esse poder, se fosse abandonado, romperia com as ilusões fundamentais da posição do sujeito masculino. A fim de "ser" o Falo, aquilo que reflete e garante uma aparente posição do sujeito masculino, as mulheres devem se tornar, devem "ser" (no sentido de que elas devem agir "como se elas fossem") precisamente o que os homens não são e, nisso que muito lhes falta, elas devem estabelecer a função essencial dos homens. Portanto, "ser" o Falo é sempre "ser para" um sujeito masculino que busca confirmar e ampliar sua identidade a partir do reconhecimento daquele "ser para". [...] A divisão e a troca entre este "ser" e "ter" o Falo é estabelecida pelo Simbólico, pela lei patriarcal (BUTLER, 2002, p. 58 [tradução nossa]).

A comunhão heteronormativa entre o ser e o ter parece se atrelar à docilidade feminina e à virilidade masculina, ambas fabricadas e mantidas pelo limite da culpa, sentimento que impede a vivência dos prazeres simples e incita a nostalgia em relação à jouissance ainda proibida ao nível da consciência, já que a perda do desejo homossexual, no caso da melancolia estruturada, é recusada como perda e assimilada como desvio moral. No que tange à matriz heterossexual, as mulheres devem sacrificar a possibilidade de uma constituição distinta de seus desejos eróticos e de sua própria subjetividade em razão da objetificação masculina, enquanto que os homens devem garantir a manifestação da virilidade, que atesta o seu potencial reprodutivo, pela negação de outras formas de amar. Os homens se nutrem das bajulações femininas e as mulheres das interjeições masculinas, de tal modo que a tentativa de amar se torna um ensaio angustiante marcado pelas cláusulas do casamento moderno. Os que detestam a angústia causada pelo desejo pudico, o qual interdita o desejo homossexual, e que ousam desbravar aquilo que poderia ser sentido para além do amor sedimentado na heteronormatividade, passam a preocupar os setores civis da saúde. A melancolia feminina/feminista e a melancolia gay resultariam da recusa do binarismo fálico a partir do qual se estabeleceria a diferença entre o ter e o ser, isto é, resultariam da recusa da elaboração normativa do desejo heterossexual. Do ponto de vista heteronormativo, a melancolia desviante romperia com a decência do Falo e, abandonando sua estrutura, reintegraria a luxúria vivida pelo louco que anunciara a morte de Deus. Logo, os masoquistas teriam se tornado inimigos fálicos ou inimigos públicos que deveriam ser detidos por uma culpa semelhante àquela vivida pelos sujeitos que mataram Deus e que se suicidaram enquanto identidades constituídas à imagem e semelhança do divino. Dessa maneira, a psicanálise parece ter contribuído, em seu limiar patriarcal, para (a) a normalização da melancolia estruturada, a qual é responsável pela arquitetura do desejo heterossexual e, portanto, pela negação da perda da possibilidade do desejo homossexual; e para (b) a patologização da melancolia criativa, processo crítico que se atrelaria à recusa do símbolo fálico.

\section{A melancolia}

As considerações de Butler sobre a linguagem patriarcal da psicanálise parecem nos mostrar que o amor é melancólico, a saber, os gemidos de amor podem conduzir tanto à renúncia de si mesmo como à recusa do Outro. Por um lado, a melancolia amorosa pode levar ao suicídio da criatividade crítica de si - este é aceito pela sociedade cujo mecanismo teria ressignificado o sacrifício cristão ao associá-lo à série de interesses desinteressados que, como nos mostra Foucault (2008), busca desde a modernidade estabelecer e preservar o bem-estar dos indivíduos: "[...] o que liga os indivíduos na sociedade civil não é o máximo de lucro na troca, [mas] é toda uma série que poderíamos chamar de 'interesses desinteressados'" (p. 409). Por outro lado, a melancolia amorosa também pode desencadear o suicídio do eu que havia sido elaborado sob a demanda do Outro, compreendido aqui como o plano normativo dos códigos e das normas socialmente aceitáveis. O suicídio do eu que introjeta o Outro favoreceria a vitalidade das capacidades criativas e subversivas do si mesmo, as quais são interditadas por uma sociedade que as concebe como fonte de atos perversos e desviantes. Mais precisamente, Butler nos explica que, com o despontar da vida psíquica do poder, a experiência do amor passa a ser concebida, conforme uma perspectiva freudiana, em virtude da economia da libido. De modo geral, para Freud, o melancólico é aquele que escolhera o seu objeto em razão da necessidade de ser amado e que, ao perdê-lo, acaba redirecionando os investimentos da libido a si mesmo:

Houve uma escolha do objeto, uma fixação da libido sobre uma pessoa determinada; em seguida, sob a influência de uma ofensa real ou de uma verdadeira decepção por parte da pessoa amada, essa relação de objeto ficou abalada. Disso não resultou o efeito normal - a retirada da libido fixada sobre esse objeto e a sua transferência a um novo -, e sim outra consequência, que parece demandar várias condições. $O$ investimento do objeto se provou pouco resistente, foi suprimido e, no entanto, a libido liberada não se deslocou para um outro objeto, mas ela se retirou no ego (Sigmund FREUD, 201 la, p. 55-56 [tradução nossa]).

Para Butler, a constituição amorosa de si mesmo é melancólica, pois ora a reflexividade nos constitui de modo a afirmar a identificação racional do si com o Outro, e neste caso a potência 
criativa do eu é abandonada, ora a reflexividade nos constitui de modo a confrontar criticamente a identificação do si com o Outro, e neste caso os limites do Outro são transgredidos e sua estrutura subvertida. De acordo com Butler, a dialética da melancolia, entendida por Freud como luto patológico, possui uma dimensão crítica que permite que o eu se constitua criativamente mediante a perda do objeto de desejo instanciado pelo Simbólico. Talvez possamos afirmar que Butler entende a melancolia como a ocasião psíquica em que a reflexividade pode vir a ser exercida de forma crítica ao invés de se restringir à culpabilidade. Em outras palavras, Butler parece potencializar essa constelação psíquica da revolta melancólica, outrora patologizada por Freud, em nome da criatividade crítica do si mesmo. ${ }^{4}$

A partir disso, Butler nos explica que a resignação dos sujeitos ao destino prescrito pela heteronormatividade psicanalítica não lhes garante uma recompensa prazerosa, mas os remonta "à relação torturante entre o Deus do Velho Testamento e aqueles servos humilhados que ofereciam a própria obediência sem recompensa. Tal sexualidade incorpora na atualidade este impulso religioso na forma da demanda por amor" (BUTLER, 2002, p. 72 [tradução nossa]). Para Butler, o amor elaborado por essa linguagem estruturada por meio da lei do patriarcado retoma alguns elementos dos flagelos religiosos, pois reitera a obediência, o sacrifício e o sofrimento de todos os indivíduos que, permanecendo incondicionalmente fiéis ao Falo, jamais atingem a perfeição heterossexual, a qual continua, entretanto, a funcionar como um horizonte transcendental de normalidade a ser constantemente reiterado e vigiado. Segundo Butler, o pudor dos desejos fálicos sempre colapsa mediante o deslumbre erótico da jouissance, cujo significado nos conduz a uma outra forma de prazer, uma forma ao mesmo tempo remota e vindoura, completamente desvencilhada do sofrimento que "reforça a sensação de limite do 'sujeito perante a lei'" (BUTLER, 2002, p. 72 [tradução nossa]).

Aparentemente, a obediência ao Falo visa compensar as frustrações e os enfados dos amores modernos pela promessa da salubridade mental e física. Então, o drama do amor moderno parece começar pelo sacrifício da criatividade crítica de si mesmo: este se aniquila na expectativa de que o Outro, afirmado como o paradigma normativo atual, seja incorporado como a consciência do eu. Em outras palavras, o si mesmo renuncia à possibilidade de uma experiência afetiva criativa em virtude da conformação ao modelo heteronormativo que vigora na sociedade. Este modo de subjetivação universal, convencional ou estruturante seria elaborado e mantido pela renúncia de uma existência que nos permitiria performar "uma vida outra para um mundo outro" (FOUCAULT, 2011 , p. 253). Por medo da insalubridade e das represálias médicas e jurídicas que dela se seguem, o si mesmo decide renunciar à sua criatividade e repetir os costumes que vigem na cultura legitimada pela máxima da Razão universal, a qual propõe que façamos tudo o que o Outro faz e sejamos tudo o que o Outro é ou tem em virtude do nosso próprio interesse desinteressado. Faz-se interessante indicar que esta forma de racionalidade, responsável por identificar o si ao Outro por meio de uma reflexão culposa no que diz respeito à norma, dá margens e abertura não só à instrumentalização da violência psicológica, mas também à instrumentalização da violência física. Muitas vezes, a violência física se constitui como um apetrecho do poder que assegura a aplicação do código e a manutenção de sua tradição em detrimento da existência de vidas que dela escapam. É deste modo, diz-nos Butler (2005), que os moralistas acabam se tornando, além de torturadores psicológicos, assassinos:

Se a vida é aquilo que deve ser degradado e destruído ao invés, digamos, de um conjunto de atos, então o castigo trabalha para destruir as condições de autonomia, corroendo, e até mesmo eviscerando, a capacidade que o sujeito interpelado tem para a autorreflexão e para o reconhecimento social, duas práticas que são, eu diria, essenciais para qualquer consideração significativa da vida ética. O castigo, é claro, também transforma o moralista em um assassino (p. 49 [tradução nossa]).

De acordo com a linguagem patriarcal da psicanálise, todos aqueles que transgridem os limites da estrutura heteronormativa na expectativa de vivenciar os prazeres de desejos perdidos, no lugar de encontrarem a alegria, encontrarão a dor que impede a maior felicidade do maior número, já que a culpa em relação à transgressão engendraria o sofrimento do melancólico gay e das melancólicas femininas/feministas. A culpa parece, sendo assim, corresponder ao instrumento por meio do qual a psicanálise teria ajustado as vigas que fundam o desejo heterossexual e que delimitam a sua normatividade. Evitamos imaginar a transformação que poderíamos ensejar por meio do suicídio do si que se constitui pelo Outro porque nós tememos recusar a elaboração de sua perda, tememos recusar o luto da perda do Outro. Dessa maneira, nós defendemos a obediência ilimitada à imagem ou à pessoa que manifesta o Falo. O indivíduo que mata o objeto fálico e suicida a identidade que resulta de sua introjeção, recusando a elaboração do luto pela perda

\footnotetext{
${ }^{4}$ Neste ínterim, torna-se interessante questionar se Butler se aproximaria da concepção aristotélica de melancolia, já que, em Problemata XXX (1956), Aristóteles busca compreender as razões pelas quais os melancólicos teriam um potencial criativo que os incitaria à filosofia, às artes e à política (ARISTOTLE. Problems II: Books XXII - XXXVIII. Tradução de W.S. Hett, M. A. Cambridge: Harvard University Press, 1956).
} 
do Outro a fim de reencontrar o desejo por si mesmo, é classificado como um doente que deve elaborar o remorso relativo a este assassinato suicida para, em seguida, retomar a saúde mental e física de um corpo cuja disposição fálica depende da normalização da melancolia estruturada. O sentimento de culpa que subsidia a obediência dos sujeitos à heteronormatividade parece atenuar a dimensão crítica de certas fantasias e atitudes, pois convence os sujeitos de que estes tipos de sonhos e de práticas são sintomas de uma tendência doentia.

Como nos mostra Butler, os recursos metafóricos da psicanálise nos remetem às simbologias religiosas. Contudo, a renúncia cristã concernente à constituição criativa de si mesmo parece se distinguir da renúncia psicanalítico-patriarcal, visto que a melancolia estruturada não conduz à elaboração de um amor oceânico fundado na transcendência da alma em relação ao corpo. Para Butler, o Falo corresponde ao símbolo que enseja a modelação do corpo e a orientação do desejo, ao passo que Deus, segundo Foucault, consistiria no símbolo por meio do qual o corpo e o desejo são purificados. Mais precisamente, para Foucault, a purificação cristã do corpo se estabelece por meio da diferenciação entre "os movimentos da alma e aqueles que se seguem da libido" (FOUCAULT, 2001, p. 995 [tradução nossa]). No cristianismo, a renúncia de si teria como finalidade a elaboração de uma consciência agraciada capaz de experienciar o amor pelo Todo. A internalização de Deus corresponderia à internalização da Totalidade: a renúncia da constituição autárquica de si mesmo visa à essencialidade da identificação entre a razão humana e a razão divina, processo responsável pelo exercício de autoridade da alma sobre o corpo. Isso significa que, para o cristianismo, o desejo é purificado quando a libido é asceticamente subsumida à procriação e, em consequência, a verdade da vontade desvelada como o amor incondicional por Deus. A renúncia das luxúrias da carne se sucede em virtude da decifração da natureza da vontade humana: "quanto mais descobrimos a verdade sobre nós mesmos, mais nós devemos renunciar a nós mesmos" (FOUCAULT, 2001, p. 991 [tradução nossa]). Dito de outro modo, os desejos são acrisolados para que a verdade da vontade se manifeste e prevaleça sobre as tentações demoníacas e as faltas individuais. Logo, a consciência do eu se institui como a consciência do Todo e o amor passa a ser vivenciado como uma experiência transcendental, isto é, o amor por si mesmo e pelos outros passa a ser concebido como o amor absoluto pelo universo.

Diferentemente, a renúncia psicanalítica da criatividade do si mesmo não se sucede em vista da transcendência da alma e da naturalização do amor oceânico, mas sim em virtude da normalização do amor heterossexual e da padronização do feminino e do masculino. O amor heterossexual deixa de ser uma manifestação da graça divina e passa a ser uma realidade imanente justificada por uma deidade que, ao invés de habitar as altitudes celestes, paira sobre as bordas da consciência, manifestando-se nas figuras sociais da mãe, do pai, da lei, da saúde, do Estado e do Capital. A linguagem patriarcal da psicanálise ratifica e retifica Deus quando o retoma sob a forma do Falo, o qual passa a operar como um fundamento psicossocial que estrutura a harmonia entre as demandas jurídicas da esfera pública e a salubridade da vida privada ou da intimidade erótico-conjugal. Por isso, a culpa ligada à perda do Falo teria o mesmo potencial da culpa relativa à morte de Deus. O sentimento de culpa parece se configurar como um instrumento de controle que age sobre o sujeito a fim de tornar voluntária a sua servidão ao Simbólico e de impedir a liberdade estética do desejo, do amor e da amizade.

\section{O cuidado de si e a melancolia desviante}

A culpa pela recusa do Falo, como a culpa pela recusa de Deus, incita a incorporação subjetiva destas imagens. A constituição heterônoma da consciência do eu conduz à experiência de amores utópicos, de amores que estariam condicionados às regras que configuram o Simbólico. Na modernidade, os vínculos sedimentados no objeto fálico estabelecem a lógica da socialização, já que os amores são vividos em decorrência da validade dos contratos que reiteram a heteronormatividade. Tais documentos recuperam as máximas religiosas que sustentavam o amor oceânico - ou seja, os preceitos que prescreviam a condicionalidade dos amantes ao Simbólico que legitima a obrigação em relação ao outro implicado em determinada associação conjugal. Os códigos fálicos parecem assegurar que os sujeitos não se atirem contra o espelho da utopia heteronormativa na medida em que eles atrelam o amor por si mesmos, proveniente da negação do Outro, à imoralidade atinente ao individualismo egoísta e ao narcisismo. Faz-se interessante destacar que esta mesma ressalva relativa à imoralidade do amor por si mesmo fora atribuída à ética foucaultiana do cuidado de si. Por exemplo, segundo Pierre Hadot (1993), Foucault teria dado lugar, ao se concentrar excessivamente na cultura do cuidado de si, a uma espécie de dandismo ético que validaria e intensificaria o individualismo egoísta vivido no presente histórico: "E eu reprovo, então, um pouco Foucault nisto que eu chamei de seu 'dandismo'. Os grandes homens de Foucault são frequentemente os dândis, como Baudelaire - as pessoas que procuraram, em primeiro lugar, ter uma bela existência" (p. 390 [tradução nossa]). Foucault nos explica que, com efeito, o cuidado de si, princípio ético difundido pelas filosofias do período helenísticoromano, pode soar aos ouvidos dos amantes modernos como "uma espécie de dandismo moral, 
afirmação-desafio de um estádio estético e individual instransponível" (FOUCAULT, 2010, p. 13). O cuidado de si pode soar aos ouvidos modernos "como a expressão um pouco melancólica e triste de uma volta do indivíduo sobre si, incapaz de sustentar, perante seus olhos, entre suas mãos, por ele próprio, uma moral coletiva (a da cidade, por exemplo), e que, em face do deslocamento da moral coletiva, nada mais então teria senão ocupar-se consigo" (FOUCAULT, 2010, p. 13). Além disso, como nos mostra Butler a propósito da psicanálise freudiana, o sujeito que se toma como objeto do seu próprio desejo e que se institui como o objetivo deste amor possuiria uma libido narcísica e colérica, própria à melancolia desviante: "De acordo com a narrativa da melancolia provida por Freud, o eu 'se volta sobre si mesmo' quando o amor falha em encontrar o seu objeto e toma a si mesmo não apenas como um objeto de amor, mas também de agressão e de ódio" (BUTLER, 1997, p. 168 [tradução nossa]).

Enquanto a melancolia estruturada assegura a socialização conforme um modelo hegemonicamente heteronormativo, a melancolia criativa a destrói, pois os sujeitos que rejeitam o Outro parecem fazê-lo em razão de uma certa decepção, a qual poderia ser compreendida como uma desilusão em relação à estrutura cultural e política que determina a subjetividade. O remorso que persegue os sujeitos lascivos possui um caráter moralizante, ou melhor, estes indivíduos são levados a pensar que a desilusão vivenciada pelo melancólico que decide desviar do Simbólico e da socialização nele estruturada desencadearia uma vida egoísta relegada à solidão narcísica. Segundo os fundamentos patriarcais da modernidade psicanalítica, o amor próprio só pode ser experienciado de forma heterônoma, como investimento jurídico-libidinal em cônjuges, familiares, colegas e concidadãos. A autarquia do cuidado de si seria incompatível com o bem-estar da sociedade civil - com a maior felicidade do maior número -, já que o indivíduo melancolicamente criativo insiste em afirmar que as convenções e as medidas que o demandam não são nada e, desse modo, que ele próprio não é nada de imutável e de absoluto. A desarticulação melancólica da substancialidade parece despontar de uma percepção desviante capaz de desvelar a comicidade por trás do drama do amor sedimentado na ontologia do Falo: "Há, com efeito, um lado cômico deste drama que é revelado a partir da manifestação da permanente impossibilidade de realização da identidade" (BUTLER, 2002, p. 72 [tradução nossa]). Descobrimos que jamais seremos perfeitamente masculinos e femininas, que jamais realizaremos com excelência imagética ou especular a heterossexualidade, visto que estas verdades fundamentais não passam de ficções inventadas e sustentadas por uma linguagem difundida por meio de saberes teóricos e práticas de poder completamente mutáveis.

Deveras, este diagnóstico crepuscular não deve ser vetado pelo remorso agraciado da religião ou pelo arrependimento analítico da ciência. Pelo contrário, talvez seja o caso de utilizálo como a estratégia capaz de incitar a subversão da utopia amorosa e da ontologia identitária, capaz de desengatilhar, por meio de um gemido prazeroso e zombeteiro, a culpa como um instrumento de coerção psicossocial. Para que os nossos desejos sejam autarquicamente liberados e para que os nossos prazeres se tornem refletidos, precisamos nos desvencilhar da culpa que nos torna coléricos e agressivos relativamente a nós mesmos. Tal esforço combativo é tão ascético quanto o cristianismo ou a psicanálise, pois cuidar de si mesmo envolve um rigor prático e crítico que tem como escopo o controle da mente e do corpo, bem como a constituição de vínculos sociais virtuosos, que decorrem do amor ético por si e pelos outros e não de uma obrigação jurídica, estatutária e simbólica. Dessa maneira, nós já somos capazes de vislumbrar as possíveis relações entre a melancolia desviante concebida por Butler e o cuidado de si helenístico-romano interpretado por Foucault.

Talvez possamos dizer que o melancólico que suicida a sua identidade fálica, como o indivíduo que se ocupa de si mesmo, torna-se objeto de seu próprio desejo e faz a experiência de um amor livre dos condicionamentos normativos do Outro. Em termos foucaultianos, parece que o melancólico desviante cuida de si por si mesmo, pois "a forma reflexiva organiza não somente a relação com o objeto - ocupar-se consigo como objeto - como igualmente a relação com o objetivo e com a finalidade. Se quisermos, uma espécie de autofinalização da relação consigo [...]" (FOUCAULT, 2010, p. 77). Parece ser neste sentido que o suicídio da identidade fixada no e pelo Outro teria sido considerado como responsável pela liberação de uma libido narcísica, ou seja, justamente porque se ocupar consigo mesmo como objeto possuiria um potencial crítico capaz de dar lugar a um modo de vida que ultrapassaria os limites da normatividade patriarcal, da qual provém a concepção de que o amor corresponde a um laço de obrigação e de dominação em relação ao amado e de que a única razão que justifica a união amorosa consiste na reprodução. Como nos explica Butler:

O ideal do eu, aquilo que Freud concebe como a "medida" em relação à qual o eu é julgado pelo super-eu, é precisamente o ideal de uma retidão social definida sobre e contra a homossexualidade. "Este ideal", escreve Freud, "tem um aspecto social: ele é também o ideal comum da família, da classe ou da nação. Ele liga não apenas a libido narcísica, mas também uma quantidade considerável da libido homossexual da pessoa, que desse modo retrai-se em 
direção ao eu. A insatisfação devida a não realização deste ideal libera a libido homossexual, a qual é transformada na sensação de culpa" (BUTLER, 1997, p. 141). ${ }^{5}$

Portanto, a nossa hipótese é a de que a melancolia criativa corresponde a um processo que desencadearia, simultaneamente, a apropriação autárquica de si mesmo e o abandono crítico da estrutura patriarcal de socialização. Este ato não ensejaria o isolamento dos indivíduos, mas, antes, a performance de amores que resistem às normas promulgadas pelas instituições que detalham o ideal da civilidade social. O desvio melancólico relativo à socialização normativa parece visar à criação de amores subversivos capazes de desmascarar a utopia fálica e de enfrentar, com franqueza, os discursos que prevalecem perante uma cultura assujeitada à demagogia filantrópica da política, da religião e da medicina. O potencial criativo da melancolia desviante residiria na atitude crítica de contra-conduta, a qual nos remonta ao cuidado de si helenístico-romano como concebido por Foucault. O melancólico, que se afasta da normalização social e que nega a culpa pela perda do Outro, parece constituir a si mesmo de modo a confrontar, por meio da sua fala, do seu corpo e da sua maneira de viver, as verdades médicas e jurídicas que continuam a vigorar na modernidade. Em outras palavras, a afirmação da criação melancólica de si mesmo transgride os limites da matriz heterossexual e subverte as proibições que fundam a nossa realidade. Sendo assim, os amores subversivos parecem constituir um "lugar de irrupção do debaixo, do embaixo, do que, na cultura não tem direito, ou pelo menos não tem possibilidade de expressão" (FOUCAULT, 2011 , p. 165). Tratase da elaboração de coexistências estéticas que não reproduziriam a essencialidade de uma nova identidade ou identificação, mas que conduziriam à criação de identidades múltiplas.

Com base nestas breves considerações, nós podemos indicar que os laços entre o cuidado de si helenístico-romano e a melancolia desviante concerniriam (a) à atitude crítica em relação à sociedade e à cultura vigentes; (b) à experiência da contra-conduta que se atrela tanto à transformação de si, quanto à interação amorosa com os outros e à intervenção no mundo; (c) à performance da franqueza no discurso e na vida; e (d) à sensação de prazer que, contrariamente às expectativas sociais, não depende da falta de controle das paixões e nem mesmo da supressão total da dor. O prazer assim experienciado se refere à alegria vivida em harmonia com o esforço ético da transformação de si, com o esforço estético relativo ao aperfeiçoamento moral da vida e com o esforço político atinente à intervenção no mundo. Parece-nos que o cuidado de si helenísticoromano e a melancolia desviante convergiriam, sobretudo, em virtude da subversão da identidade, a qual se faz possível em detrimento da substancialização dos valores do bem, do belo e do verdadeiro. Com efeito, os conceitos aqui apontados devem ser refinados e as hipóteses mais bem desenvolvidas. Contudo, acreditamos que a indicação destas problematizações já nos permite entrever a tese segundo a qual a autarquia crítica, no caso da estética da existência e no da melancolia desviante, seria capaz de conduzir à constituição de diversas e finitas coexistências sociais, estimuladas pela experiência de amizades e de amores subversivos, isto é, de laços afetivos que resistem ao funcionamento institucional e normativo dos poderes articulados a saberes que consolidam cabalmente a verdade sobre a natureza humana.

\section{Referênclas}

BRENNAN, Tad. "Psicologia moral estoica". In: INWOOD, Brad (Org.). Os Estoicos. Tradução de Paulo Fernando Tadeu Ferreira e Raul Fiker. São Paulo: Odysseus, 2006. p. 285-327.

BUTLER, Judith. Gender Trouble: feminism and subversion of identity. London: Taylor \& Francis eLibrary, 2002.

BUTLER, Judith. Giving an Account of Oneself. New York: Fordham University Press, 2005.

BUTLER, Judith. The Psychic Life of Power: Theories in Subjection. California: Stanford University Press, 1997.

BUTLER, Judith. What is Critique? An Essay on Foucault's Virtue, 2001. Disponível em http://eipcp.net/ transversal/0806/butler/en. Acesso em 26/01/2017.

DIOGENES LAERTIUS. Live of Eminent Philosophers. Tradução de R. D. Hicks. Cambridge: Harvard University Press, 1972.

EPICTETO. O Encheirídion de Epicteto. Tradução de Aldo Dinucci e Alfredo Julien. São Cristóvão: EDUFS, 2012. (Cap. 11)

\footnotetext{
${ }^{5}$ A caracterização freudiana do ideal do eu pode ser verificada em Pour introduire le narcissisme (FREUD, Sigmund. Pour introduire le narcissisme. Tradução de Olivier Mannoni. Paris: Payot \& Rivages, 2012). Já a explicação da instância do supereu pode ser estudada em O mal-estar na civilização (FREUD, Sigmund. O mal-estar na civilização. Tradução de Paulo César de Souza. São Paulo: Companhia das letras, 2011 b).
} 
FOUCAULT, Michel. A Hermenêutica do Sujeito. Tradução de Márcio Alves da Fonseca e Salma Tannus Muchail. São Paulo: Martins Fontes, 2010.

FOUCAULT, Michel. A Coragem da Verdade. Tradução de Eduardo Brandão. São Paulo: Martins Fontes, 2011 a.

FOUCAULT, Michel. A História da Sexualidade 3: O cuidado de si. Tradução de Maria Thereza da Costa Albuquerque. São Paulo: Graal, 2011 b.

FOUCAULT, Michel. Dits et écrits II. 1976-1988. Paris: Gallimard, 2001.

FOUCAULT, Michel. Nascimento da Biopolítica. Tradução de Eduardo Brandão. São Paulo: Martins Fontes, 2008.

FREUD, Sigmund. Deuil et mélancolie. Tradução de Aline Weill. Paris: Payot \& Rivages, 2011 a.

FOUCAULT, Michel. Do governo dos vivos. Tradução de Eduardo Brandão. São Paulo: Martins Fontes, 2014.

HADOT, Pierre. Exercices Spirituels et Philosophie Antique. Paris: Albin Michel, 1993.

LACAN, Jacques. O Seminário, Livro 8: A Transferência. Tradução de Dulce Duque Estrada. Rio de Janeiro: Zahar, 2010.

NIETZSCHE, Friedrich. A Gaia e a Ciência. Tradução de Paulo César de Souza. São Paulo: Companhia das Letras, 2012.

PLUTARCO. Como distinguir o amigo do bajulador. Tradução de Ísis Borges B. da Fonseca. São Paulo: Martins Fontes, 2011.

Cassiana Lopes Stephan (cassianastephan@yahoo.com.br) é doutoranda em Filosofia pela Universidade Federal do Paraná (UFPR) na área de Ética e Política, com estágio de pesquisa no Laboratoire Savoirs, Textes, Langage (UMR 8163) da Université de Lille, entre setembro de 2018 e abril de 2019, e no Institut Mémoires de l'Édition Contemporaine (IMEC) em razão da primeira bolsa de estudos da Association pour le Centre Michel Foucault (CMF) em parceria com o IMEC, de julho a setembro de 2019.

\section{COMO CITAR ESSE ARTIGO DE ACORDO COM AS NORMAS DA REVISTA}

STEPHAN, Cassiana Lopes. "Notas sobre o amor e a melancolia: da estrutura à resistência". Revista Estudos Feministas, Florianópolis, v. 28, n. 2, e59368, 2020.

\section{CONTRIBUIÇÃO DE AUTORIA}

Não se aplica.

\section{FINANCIAMENTO}

O presente trabalho foi realizado com apoio da Coordenação de Aperfeiçoamento de Pessoal de Nível Superior - Brasil (CAPES) - Código de Financiamento 001, no quadro do Programa de Doutorado Sanduíche no Exterior (PDSE), o qual se sucedeu na Université de Lille - École Doctorale Sciences de l'Homme et de la Société.

\section{CONSENTIMENTO DE USO DE IMAGEM}

Não se aplica.

APROVAÇÃO DE COMITÊ DE ÉTICA EM PESQUISA

Não se aplica.

\section{CONFLITO DE INTERESSES}

Não se aplica. 
NOTAS SOBRE O AMOR E A MELANCOLIA: DA ESTRUTURA À RESISTÊNCIA

LICENÇA DE USO

Este artigo está licenciado sob a Licença Creative Commons CC-BY International. Com essa licença você pode compartilhar, adaptar, criar para qualquer fim, desde que atribua a autoria da obra.

HISTÓRICO

Recebido em 19/10/2018

Reapresentado em 06/08/2019

Aprovado em 22/10/2019 